\title{
EVALUATION OF OKRA CULTIVARS AND BREEDING LINES FOR AGRONOMIC TRAITS IN UMUDIKE IN SOUTHEASTERN NIGERIA
}

\author{
P. I. OKOCHA and L. N. CHINATU
}

(Received 10 April, 2007; Revision Accepted 26 September, 2007)

\section{ABSTRACT}

Six (6) genotypes comprising two (2) cultivars and four (4) breeding lines of Okra (Abelmoschus esculentus (L) Moench) were studied in a randomized complete block design with three (3) replicates to determine their performance under Umudike environmental conditions in 2002 and 2003 cropping seasons. With respect to fresh pod yield, all the genotypes performed very well in both years, although the breeding lines performed better than the two (2) varieties. Breeding lines LD88/1-8-16-2 and LD88/1-8-13-2-4 recorded fresh pod yields of 3.6 and 3.2 t/ha in 2002, 3.5 and $3.3 \mathrm{t} / \mathrm{ha}$ in 2003 respectively, which are well above the fresh pod yields recorded for Okra in the tropics. The early maturing Okra genotypes used in the present study with 3 to 4 months duration present a possibility of growing two crops of Okra (early and late croppings) in one year, unlike the indigenous photoperiod sensitive varieties with eight to nine months duration.

KEY WORDS: Okra, cultivars, breeding lines, and Agronomic traits

\section{INTRODUCTION}

Okra (Abelmorchus esculentus ( $L$ ) Moench) belongs to the family, Malvaceae and is one of the most important vegetable crops cultivated in the tropical and sub-tropical regions of the world, under rainfed or irrigation conditions (Libby, 1968; Agunloye, 1986). Tindall (1983) and Fashakun (1980) reported that Okra contains moderate levels of some essential minerals and vitamins, which are important for metabolic processes that utilize carbohydrates, proteins and fats.

Okra seeds contain $2 \%$ protein, $14 \%$ lipids and $5 \%$ ash. However, upon removal of the seedhull by grinding, 33\% protein, $25 \%$ lipids and $6 \%$ ash were recorded. Also substantial amount of saturated and unsaturated fatty acids were found in the ratio of 1: 1.55, (Savello et al., 1980).

Due to unstable yield which are sometimes low, breeding for high and stable yield in Okra is essentially important (Akoroda, 1986). Replacement of local and indigenous varieties/ species that grow very tall, with high abortion rate and long life cycle of 8-9 months (Kehinde 1999) with high yielding varieties of shorter life cycle (3-4 months) will improve yield.

The indigenous Okra varieties are predominantly cultivated by the local farmers in Umudike. Identification of Okra genotypes which are suitable for southeastern environment will increase the prospect of growing two crops of Okra a year. Thereby enhancing increased Okra production. Therefore, the objective of this study is to determine which of the Okra genotypes would be suitable for the southeastern environmental conditions.

\section{MATERIALS AND METHODS:}

Six (6) Okra genotypes (obtained from National Horticultural Research Institute, Ibadan) were used in the study. These include two (2) varieties; NHAe 47-4 and LD88 and four breeding lines: LD88/1-8-13-2-4, LD88/1-8-13-2-5 LD88/1-8-16-2 and LD 88/1-8-27-1. The field experiments were carried out in 2002 and 2003 early cropping seasons at the Michael Okpara University of Agriculture Research Farm, Umudike. The study location has an average rainfall of $2200 \mathrm{~mm}$ per annum, and lies within longitude $07^{0} 34^{1}$, and Latitude $05^{0} 29^{1} \mathrm{~N}$, and is $122 \mathrm{~m}$ above sea level, (National Root crops Research Institute Meteorological Station, Umudike).

The experiment was a randomized complete block design (RCBD) with three replications. A total of 18 plots each measuring $1.8 \times 1.2 \mathrm{~m}$, with a distance of $0.6 \mathrm{~m}$ separating the plots and $1 \mathrm{M}$ separating the blocks was used. Each plot had 3 (three) rows. Each row was $1.8 \mathrm{~m}$ long. The total experimental area was $13.8 \times 5.6 \mathrm{~m}$ or $77.28 \mathrm{~m}^{2}$.

In 2002 and 2003, the seeds of the Okra were planted three (3) per hole at a spacing of $0.6 \mathrm{X} 0.6 \mathrm{~m}$ between and within rows. Supplying of missing hills, which brought germination count to $100 \%$, was done 10 days after planting. Plants were thinned down to one per stand, three weeks after seedling emergence, giving a total plant population of approximately 27,778 plants/ ha.

Compound fertilizer, NPK (20: 10: 10) was applied at the rate of $500 \mathrm{~kg} / \mathrm{ha}$, four weeks after planting, using ring method of application. Weeding was done manually using hoe at three (3) Six (6) and nine (9) weeks after planting.

Karate (Lambda-cyhadrothrin; containing $25 \mathrm{~g}$ of lambda-cyhadrothrin per litre) brand of insecticide was applied at the rate of $800 \mathrm{ml} /$ ha to control insect pest (Podagrica Spp) attack. Data collected were on the following attributes: plant height, number of buds/plant, number of flowers/ plant, number of pods/plant, podlength at maturity, dry pod weight, pod yield/ plant, 100 seed-weight, fresh pod yield/ hectare and rate of flower abortion. The rate of flower abortion was deduced as follows: the total number of flowers and pods per plant were counted from the time of flower production from five tagged plants per plot.

Rate of flower abortion $(\%)=\underline{\text { Total number of flowers }- \text { Total number of pods }} \times \underline{100}$

Total number of flowers $\frac{100}{1}$

Date were subjected to analysis of variance and means were separated using Duncan's New multiple Range Tests. Correlation analysis was also carried out for both years.

\section{RESULTS AND DISCUSSION}

The results of the experiments are presented on Tables 1, 2, 3 and 4 . The plant height varied from 76 to $125 \mathrm{~cm}$ in 2002 and from 69 to $99 \mathrm{~cm}$ in 2003. Akoroda (1986) recorded mean heights of $116.1,98.5,91.4,131.6$ and $109.0 \mathrm{~cm}$ for the improved genotypes; Um80, NHAe 47-4, Tae 38 and NHAe 394, respectively. Tindall (1983) reported mean heights of up to $200 \mathrm{~cm}$ for unimproved genotypes.

In 2002 and 2003, the breeding lines, LD88/1-8-13-24, LD88/1-8-16-2, LD88/1-8-13-2-5 and LD88/1-8-27-1 were 
significantly taller $(\mathrm{P}<0.05)$ than the varieties; NHAe $47-4$ and LD88 (Tables 1 and 2).

Brown (1989) reported that plant height is closely correlated with flowering, fruit parameter and structure in Abelmoschus esculentus (L) Moench. He used the correlation coefficients to pick the high yielding varieties. In this study, positive and high correlation coefficents of 0.86 and 0.79 $(P<0.05)$ in 2002 and 2003, respectively between plant height and fresh pod yield/ hectare were obtained, (Tables 3 and 4). The findings from this work showed that plant height significantly $(P<0.05)$ is affected fresh pod yield of the genotypes (Tables 1, 2, 3 and 4).

The number of leaves/ plant varied from 39 to 55 and from 37 to 56 in 2002 and 2003, respectively. The breeding lines: LD88/1-8-27-1, LD88/1-8-16-2 and LD88/1-8-13-2-5 produced the largest number of leaves which each year differed significantly $(\mathrm{P}<0.05)$ from those produced by the varieties. Number of leaves/ plant associated positively and strongly with fresh pod yield/hectare in both years (Tables 3 and 4). It was observed that these breeding lines also recorded fresh pod yields/ hectare that were significantly higher than those of the varieties (Tables 1 and 2).

Number of lateral branches/ plant varied from 3 to 4 in 2002 and from 1.8 to 2.6 in 2003. The genotypes differed significantly $(P<0.05)$ with respect to lateral branching (Tables 1 and 2). Akoroda (1986), recorded values for lateral branching for genotypes NHAe 47-4, 8p-1-1, and 8p-1-7 as 2.1, 2 and 2 respectively. Positive and strong associations were deduced between number of lateral braches and fresh pod yield/ hectare (Table 3 and 4). Osekita et al., (2000), reported that branching had significant effect on Okra fresh pod yield. The findings from this work also showed that lateral branching significantly $(P<0.05)$ affected the yield of the genotypes under study (Tables 1and 2).

Ajibade and Morakinyo (2000), reported that vegetation characters (Plant height, number of leaves / plant and number of lateral branches / plant) determine the amount of photosynthates available for plant growth, fresh pod and seed yield. Tenebe et al., (1985) had reported that vegetative characters are strongly associated with high yields in cow pea. The findings from this work showed that the genotypes with better vegetative growth recorded higher fresh pod yields. (Table 1 and 2).

The results for the number of buds/ plant, number of flowers / plant and number of pods/plant are presented on Tables ( 1 and 2$)$. The genotypes differed significantly $(P<0.05)$ with respect to each character in 2002. The same trend was observed in 2003. Duncan's New Multiple Range Test was used to separate the means of the characters (number of buds/ plant, number of flowers/ plant and number of pods/ plants) (Tables 1 and 2). Number of flowers and number of pods/plant associated positively and strongly with fresh pod yield / hectare with coefficients of $0.81,0.91$ and $0.70,0.77$ in 2002 and 2003, respectively (Tables 3 and 4).

Number of pods/plant varied from 5.33 to 8.67 and from 5.20 to 9.00 in 2002 and 2003, respectively (Tables 1 and 2). Akoroda et al. (1987) reported an average of 3.93, 4.87 and 4.75 for dry pods/ plant on NHAe 47-4, Tae 38 and OP80 Varieties of $A$. esculentus (L) moench, respectively. Kehinde (1999) at Abeokuta reported an average of 8 to 10 pods/plant on 6 lines of West African Okra, (A. Caillei). These showed that the rate of pod production, which represents Okra fresh pod yield of these genotypes, is high in southeastern Nigeria. In 2002, the breeding line L088/1-8-13-2-5, had the largest number of pods/ plant (8.67), while the variety NHAe 47-4 produced the lowest number of pods/ plant (5.33). NHAe 47-4 (variety) also bore lowest number of pods/ 15.20, while LD88/1-8-13-2-4 (breeding line) recorded the highest number of pods/plant (9.00). in 2003.

The results of pod length, dry pod weight and 100 seed weight are presented on Tables (1 and 2). The genotypes differed significantly $(P<0.05)$ with respect to each character (pod length, dry pod weight and 100 seed-weight), in each year. (Tables 1 and 2). The three characters associated weakly with fresh pod yield / hectare, with pod length and dry pod weight having negative coefficients $(P>0.05)$ in both years (Tables 3 and 4). Genotypes with longer pods of higher dry weight bore fewer pods and vice versa. By inferences, increase in number of pods/ plant led to significant $(p<0.05)$ increase in fresh pod yield /hectare. Increase in pod length, dry pod weight and 100 seed weight however, could not lead to increase in fresh pod yield /hectare in both years (Tables 1,2, 3 and 4). Hence, the genotypes (breeding lines) with higher number of pods/ plant, moderate pod length and dry pod weight recorded higher fresh pod yield/ hectare, (Tables 1 and 2).

Akoroda et al., (1987) reported that pod length is so significant (distinctive feature) that it could serve as the basis of classification of Okra genotypes. The findings from this work showed that dry pod weight and pod length clearly differentiated $(P<0.05)$ the varieties from the breeding lines (Tables 1 and 2).

The results of the rate of flower abortion are presented on Tables 1 and 2. The genotypes differed significantly $(P<0.05)$ in each year with regards to rate of flower abortion and varied from 19.40 to $35.2 \%$ and from 19.40 to $34.01 \%$ in 2002 and 2003, respectively (Tables 1 and 2).

Rates of flower abortion also correlated strongly but negatively with number of pods/plant and fresh pod yield/ hectare, (Tables 3 and 4). This means that the higher the rate of flower abortion the lower the fresh pod/ yield. This explains why in both years genotypes with the lowest flower abortion rate (LD88/1-8-16-2) recorded the highest fresh pod yield I hectare, and vice versa (Tables 1, 2, 3 and 4).

Tindal (1983), Akoroda (1986), Grubben (1977) and purseglove (1968) reported yields of about 1 to 3 metric tons / hectare (1000 to $3000 \mathrm{~kg} /$ hectare) in the tropics. The values obtained from the varieties used in the present study are slightly lower than the highest values reported by these earlier workers, but the yield values of the breeding lines, especially LD 88/1-8-16-2 and LD88/1-8-13-2-4 are higher than the values reported by these earlier workers. These imply that the genotypes performed well in southeastern Nigeria.

Most of the varieties used within Umudike are West African Okra types, A Caillei, which have high yield potentials but are photoperiod sensitive with about 8 months life cycle. Hence they are cropped once in a year. These genotypes used in this study can complete their life cycle in 3 to 4 months, hence can be cropped twice in a year. 
Table 1: Agronomic Characteristics of Okra genotypes in Umudike in 2002

\begin{tabular}{|c|c|c|c|c|c|c|}
\hline Plant Attributes & NHAe 47-4 & LD88 & LD88/1-8-13-2-4 & LD88/1-8-16-2 & LD88/1-8-13-2-5 & LD88/1-8-27- \\
\hline Plant height $(\mathrm{cm})$ & $76.30^{\mathrm{d}}$ & $78.90^{d}$ & $108.80^{\mathrm{bc}}$ & $124.50^{\mathrm{a}}$ & $103.10^{\mathrm{bc}}$ & $95.60^{c}$ \\
\hline Number of leaves/plant & $39.00^{d}$ & $49.80^{b c}$ & $49.80^{\mathrm{bc}}$ & $54.20^{a b}$ & $55.10^{\mathrm{a}}$ & $50.00^{a b}$ \\
\hline $\begin{array}{l}\text { Number of lateral } \\
\text { branches/plant }\end{array}$ & $3.33^{b}$ & $3.50^{a b}$ & $3.67^{a b}$ & $3.89^{\mathrm{a}}$ & $3.78^{a b}$ & $3.22^{b}$ \\
\hline Number of buds/plant & $13.33^{\mathrm{cd}}$ & $12.67^{d}$ & $16.22^{a b}$ & $15.44^{\mathrm{abc}}$ & $16.33^{a b}$ & $17.22^{\mathrm{a}}$ \\
\hline Number of flowers/plant & $7.89^{c}$ & $8.78^{\mathrm{bc}}$ & $11.11^{\mathrm{a}}$ & $10.44^{\mathrm{a}}$ & $11.33^{\mathrm{a}}$ & $11.78^{\mathrm{a}}$ \\
\hline Number of pods/ plant & $5.33^{c}$ & $5.78^{c}$ & $8.22^{a b}$ & $8.44^{\mathrm{ab}}$ & $8.67^{\mathrm{a}}$ & $8.22^{a b}$ \\
\hline Pod length $(\mathrm{cm})$ & $11.79^{\mathrm{a}}$ & $11.18^{\mathrm{ab}}$ & $7.99^{\mathrm{C}}$ & $8.22^{c}$ & $7.53^{c}$ & $7.56^{\mathrm{c}}$ \\
\hline Dry pod weight (g) & $14.36^{\mathrm{a}}$ & $15.97^{\mathrm{a}}$ & $10.11^{\mathrm{cd}}$ & $10.57^{\mathrm{bc}}$ & $10.04^{\mathrm{cd}}$ & $9.93^{\mathrm{cd}}$ \\
\hline Rate of flower abortion & $30.28^{b}$ & $35.27^{\mathrm{a}}$ & $21.64^{d}$ & $19.40^{\mathrm{C}}$ & $21.80^{d}$ & $29.59^{b c}$ \\
\hline 100 seed weight & $7.13^{\mathrm{a}}$ & $6.41^{\mathrm{b}}$ & $5.49^{\mathrm{e}}$ & $6.36^{\mathrm{bc}}$ & $6.20^{\mathrm{c}}$ & $6.23^{b c}$ \\
\hline Fresh pod yield (tons/hectare) & $2.69^{d}$ & $2.97^{d}$ & $3.24^{b}$ & $3.55^{\mathrm{a}}$ & $3.08^{b c}$ & $2.98^{\mathrm{bc}}$ \\
\hline
\end{tabular}

Means within the same row followed by the same letter are not significantly different at $5 \%$ probability level.

Table 2: Agronomic Characteristics of Studied Okra genotypes in Umudike in 2003

Plant Attributes

NHAe 47-4 LD88

Plant height (cm)

Number of leaves/plant Number of

branches/plant

Number of buds/plant

Number of flowers/plant

Number of pods/plant

Pod length (cm)

Dry pod weight (g)

Rate of flower abortion (\%)

100 seed weight $(\mathrm{g})$

Fresh pod yield (tons/hectare)

$77.67^{\mathrm{d}}$

$36.67^{d}$

lateral $2.54^{\mathrm{a}}$

$13.00^{d}$

$18.00^{\mathrm{C}}$

$5.20^{\mathrm{C}}$

$10.84^{\mathrm{ab}}$

$14.19^{\mathrm{b}}$

$33.64^{a b}$

$7.14^{\mathrm{a}}$

$66.83^{\mathrm{e}}$

LD88/1-8-13-2-

LD

$36.78^{\mathrm{d}} \quad 45.78^{\mathrm{c}}$

$1.89^{\mathrm{bc}}$

$1.89^{\mathrm{C}}$

$12.44^{\mathrm{d}} \quad 16.00^{\mathrm{bc}}$

$8.67^{\mathrm{c}} \quad 11.00^{\mathrm{ab}}$

$5.78^{\mathrm{c}} \quad 9.00^{\mathrm{a}}$

$11.24^{\mathrm{a}} \quad 7.85^{\mathrm{cd}}$

$15.83^{\mathrm{c}} \quad 10.05^{\mathrm{cd}}$

$34.01^{\mathrm{a}} \quad 21.42^{\mathrm{d}}$

$6.44^{\mathrm{a}}$

$5.48^{\mathrm{d}}$

$2.77^{\mathrm{d}}$

$3.26^{\mathrm{ab}}$ $95.89^{\mathrm{ab}}$

$52.89^{\text {ab }}$

$1.78^{\mathrm{c}}$

$15.33^{\mathrm{C}}$

$10.56^{\mathrm{ab}}$

$8.55^{\mathrm{ab}}$

$8.02^{\mathrm{cd}}$

$10.30^{\mathrm{cd}}$

$19.40^{\mathrm{e}}$

$6.31^{\mathrm{b}}$

$3.54^{\mathrm{a}}$
LD88/1-8-13-25

$99.29^{\mathrm{a}}$

$33.56^{\mathrm{a}}$

$2.33^{\mathrm{ab}}$

$16.56^{\mathrm{ab}}$

$12.44^{\mathrm{a}}$

$8.67^{\mathrm{ab}}$

$7.28^{\mathrm{d}}$

$9.98^{\mathrm{cd}}$

$21.9^{\mathrm{d}}$

$6.10^{\mathrm{bc}}$

$3.07^{\mathrm{bc}}$

Means within the same row followed by the same letter are not significantly different at $5 \%$ probability level.

LD88/1-8-27-

1

$90.64^{\mathrm{bc}}$

$50.58^{\mathrm{ab}}$ $2.56^{\mathrm{a}}$

$17.22^{\mathrm{a}}$

$11.89^{\mathrm{a}}$

$8.33^{\mathrm{ab}}$

$7.40^{\mathrm{cd}}$

$9.83^{\mathrm{d}}$

$29.39^{\text {bc }}$

$6.09^{\mathrm{bc}}$

$3.02^{\mathrm{bc}}$ 


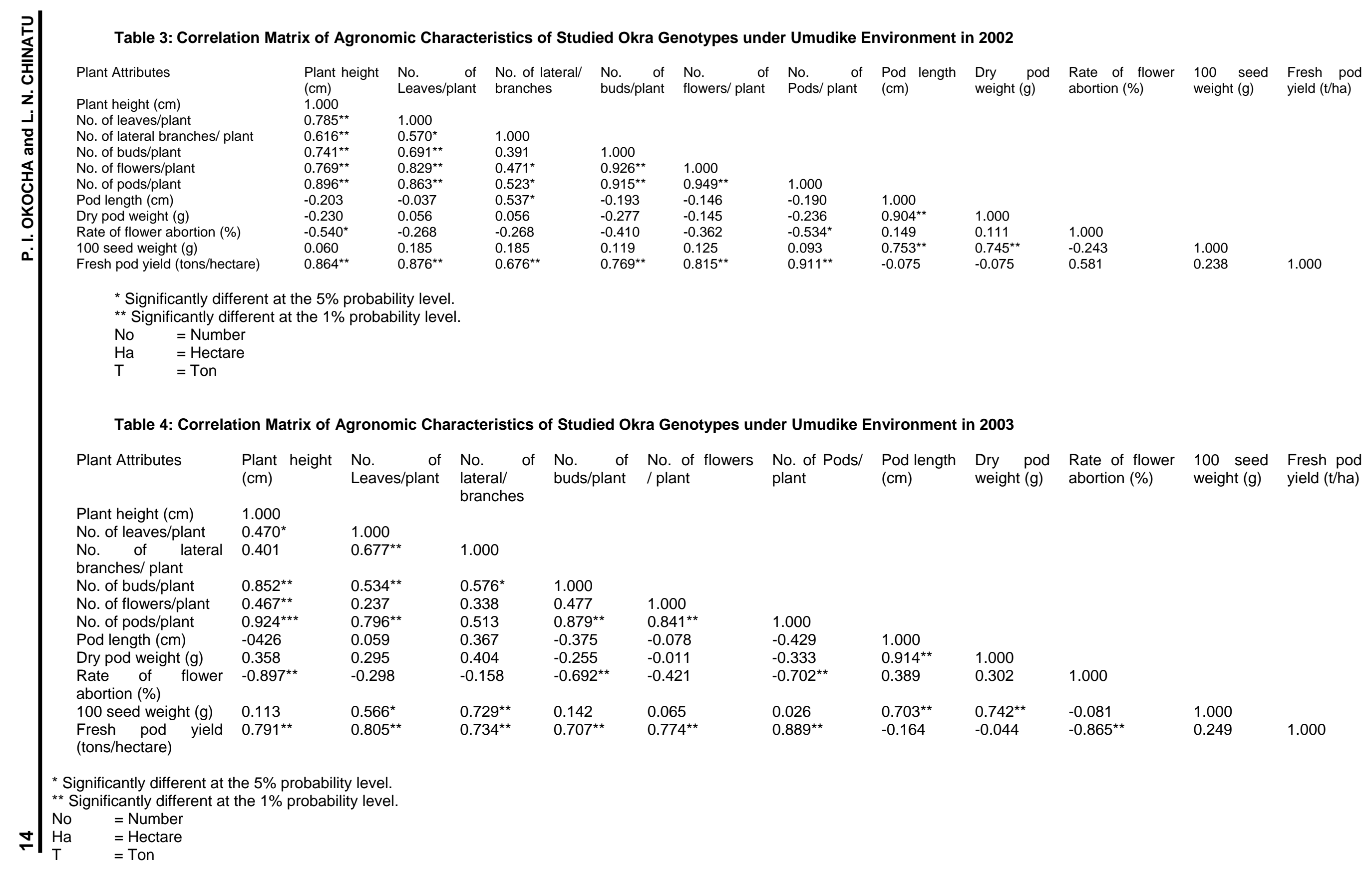




\section{CONCLUSION}

Within the okra genotypes studied, high performance of the vegetative traits (plant height, number of leaves/ plant and lateral branches) and yield character (number of pods / plant) led to high fresh pod yield. Hence steps should be taken to release the breeding lines LD88/1-8-16-2 and LD88/1-8-132-4, as varieties to farmers to increase okra fresh pod production in Southeastern Nigeria. Due to the short life cycle (3 to 4 months) of these genotypes, two seasons okra cropping in a year is highly feasible with the aid of irrigation during dry season.

\section{REFERENCE}

Agunloye, O.,1986. Effects of Cypermetrin on the population of Podagrica uniforma (Jacoby) and Podagrica Sjostedi (Jacoby) on the yield of Okra. Tropical Pest Management 32 (1), pp 55-56.

Ajibade, S. R. and Morakinyo, J. A., 2000. Heritability and Correlation Studies in Cowpea (Vigna unguiculata (L) Walp). Nig. J. of Genet 15: 29-33.

Akoroda, M. O., 1986. Allogamy, Varietal Adulteration and the breeding of okra (Abelmosch esculentus (Moench) Nig. J. of Agric-Science. 106: 313-321.

Akoroda, M. O, Alice, P.O., Atiri, G. I. and Babatola, J. O.,1987. Diversity in 265 Accessions of okra from 12 countries of Africa. NIHORT Ibadan p. 5

Brown, A. H. D., Frankel, O. H. and Williams, J. T., 1989. The use of Plant Genetic Resources. New York, Cambridge University Press, P. 187.

Fashakun, J. B., 1980. The role of horticulture in the green revolution. Keynote address presented at the $3^{\text {rd }}$ Annual Conference of the Horticultural society of Nigeria. Ibadan, Nigeria.
Kehinde, O. B., 1999. Floral Biology of West Africa Okra Nig. J. of Genetics: 14: 14 - 97.

Libby, J. L., 1968. Insect Pest of Nigerian crop. University of Ife / MANR/USAID/ University of Wiscosin Research Bullet, N0 269: P. 69.

Messiah, C. M., 1992. The tropical vegetable Garden. CTA, London Macmillan Press Ltd pp. 441-442.

Obi, I. U., 2002. Statistical Method of Detecting Differences Between Treatment Means and Research Methodology Issues in Laboratory and Field Experiments. Nsukka, AP Express Publishers Limited, Nigeria, p69.

Onyenwe, C. N. and Udeogalanya, A. C. C., 1987. Genetics of some seed yield components in okra (Abelmoschus esculentus (L) Moench). Proceeding of the $9^{\text {th }}$ Annual Conference of the HORTSON pp 10-12.

Osekita, O. S., Ariyo, O. J. and Kehinde, O. B., 2000. Variation and inter-character association in the segregation $F_{3}$ population arising from two crosses of Okra (Abelmoschus esculentus mill and L. Pim Pimpinellitolium jush). Moor J. Agric Res 1: 32-36.

Purseglove, J. W., 1968. Tropical crops; dicotyledons-London, Longman pp. 368-371.

Savello, P. A., Martin, F. W. and Hill, J. M., 1980. Nutrional composition of Okra seedmeal. J. Agric. And Food Chem. 28: 1163-1166.

Tenebe, V. A., Yusuf Kaigama, B. K. and Asenime, I. E. O., 1985. The Effect of sources and levels of phosphorus on the growth of cowpea (Vigna Unguiculata (L) Walp) varieties. Tropical Sciences 35: 223-228.

Tindal, H. D., 1983. Vegetables in the trooics. Hong Kong. The Macmillian Press Ltd. Pp 225-337. 